Lutsik Julia, Mazka Sergey, Mirnenko Volodymyr, Begma Vitaliy, Ulianov Kostyantin \& Yurkiv Nadiia (2019) Pidvyshchennya efektyvnosti derzhavnoho finansovoho kontrolyu za rakhunok vprovadzhennya systemy ryzyk-oriyentovanoho planuvannya [Improving the effectiveness of public financial control through the introduction of risk-oriented planning]. Social development \& Security. 9(4), 41 - 60. DOI: http://doi.org/10.33445/sds.2019.9.4.3

\title{
Підвищення ефективності державного фінансового контролю за рахунок впровадження системи ризик-оріснтованого планування
}

\author{
Юлія Луцик*, Володимир Мірненко**, Віталій Бегма***, Сергій Мазка****, \\ Костянтин Ульянов *****, Надія Юрків ****** \\ * Національний університет оборони України імені Івана Черняховського, \\ пр. Повітрофлотський, 28, м. Київ, 03049, Україна, \\ e-mail: julia.lutsik@gmail.com, \\ к.е.н., \\ дочент кафедри економіки та фінансового забезпечення. \\ ** Національний університет оборони Украӥни імені Івана Черняховського, \\ пр. Повітрофлотський, 28, м. Київ, 03049, Україна, \\ e-mail: mirnenkovi@gmail.com, \\ д.m.н., професор, Заслужений працівник освіти Украӥни, \\ завідувач кафедри логістики Повітряних Сил. \\ *** Національний інститут стратегічних досліджень, \\ вул. Пирогова, 7а, м. Київ, 01030, Україна, \\ e-mail:begma@niss.gou.ua, \\ д.е.н., доиент, \\ провідний науковий співробітник.
}

**** Центральне територіальне управління внутрішнього аудиту Департаменту внутрішнього аудиту Міністерства оборони України,

вул. Стрілецька, 23, м. Вінниця, Україна,

e-mail: akulacristal@gmail.com,

заступник начальника управління,

***** Незалежний сертифікований аудитор

e-mail: uluanov132@gmail.com

к.е.н.

****** Національний інститут стратегічних досліджень,

вул. Пирогова, 7а, м. Київ, 01030, Україна,

e-mail:yurkiv_n@ukr.net,

д.e.н., nрофресор,

головний науковий співробітник відділу фінансової безпеки.

\begin{tabular}{|c|c|}
\hline OPEN ACCESS & $\begin{array}{l}\text { Анотація: Однією із важливих міжнародних практик } \\
\text { внутрішнього аудиту є застосування ризик-орієнтованого }\end{array}$ \\
\hline Article history: & планування при виборі об’єктів та суб’єктів аудиту. В процесі \\
\hline Received: June, 2019 & дослідження проаналізовано відповідність діяльності 3 \\
\hline 1st Revision: July, 2019 & внутрішнього аудиту національним стандартам 3 одночасною \\
\hline Accepted: August, 2019 & імплементацією міжнародних стандартів професійної практики \\
\hline
\end{tabular}


в процесі здійснення ризик-орієнтованого планування аудиторської діяльності та вивчення практичного ефекту від впровадження системи ризик-орієнтованого планування.

Доведено, що станом на сьогодні, сил підрозділів служби внутрішнього аудиту є недостатньо для проведення суцільної перевірки всіх військових частин, установ, організацій Міністерства оборони України. Сформульована необхідність у якісному плануванні заходів аудиторських перевірок з метою охоплення саме таких об'єктів, в яких ідентифіковано найбільші загрози та ризики.Питання ризик-орієнтованого планування внутрішнього аудиту розкрито в наступній логічній послідовності: визначено загальну регламентацію зазначеного процесу, проведено аналіз складових ризик-орієнтованого планування та запропоновано методику розробки плану на підставі ризик-орієнтованого відбору об'єктів аудиту. Зокрема, детально розглянуто питання стосовно визначення ризиків, проведення оцінки ризиків за відповідними критеріями, визначення ризиків за допомогою балів. В ході проведеного дослідження емпірично підтверджено та теоретично доведено, що ризик-орієнтоване планування $\epsilon$ невід’ємною і важливою складовою аудиторської діяльності. Доведено важливість даного напрямку в контексті отриманого економічного ефекту від превентивних заходів. На основі зробленого аналізу, виявлено наявні проблеми і обгрунтовано комплекс теоретичних і практичних рекомендації з метою удосконалення зазначеного процесу в Міністерстві оборони України та практичного застосування розроблених методичних підходів із ризик-орієнтовного планування. Результати проведеного дослідження можуть бути корисними в процесі планування аудиторської діяльності на відповідний період.

Ключові слова: аудит, планування аудиту, ідентифікація подій, оцінка ризиків, ризикорієнтоване планування.

\section{1. Формулювання проблеми}

\section{1. Новизна дослідження}

Підвищення ефективності використання державних фінансів, матеріальних та інших ресурсів, має вирішальне значення для економічного розвитку країни, відповідно і Міністерства оборони в тому числі. Важливим інструментом, що дозволяє досягти бажаного економічного ефекту в державному секторі економіки є система державного внутрішнього фінансового контролю.

В схваленій Урядом Стратегіï реформування системи управління державними фінансами на 2017-2020 роки (2017) однією із визначених цілей $\epsilon$ підвищення ефективності державного фінансового контролю. Результативним показником ефективності $є$ - частка об'єктів контролю, відібраних на основі ризик-орієнтованого підходу. Однією із важливих міжнародних практик внутрішнього аудиту є застосування ризик-орієнтованого планування при виборі об'єктів та суб'єктів аудиту. Якісною ознакою ефективності є динаміка змін показника: збільшення частки свідчить про зростання ефективності i зменшення - навпаки про зниження ефективності.

Новизна та актуальність вирішення даної наукової проблеми полягає в тому, що на сьогоднішній день аудиторська служба перебуває на етапі реформування, як в Міністерстві оборони України, так і на загальнодержавному рівні (Указ Президента України 240/2016, 2016; Постанова Кабінету Міністрів України № 1062, 2018), відповідно всі питання, які пов'язані із процесом становлення i розвитку системи державного внутрішнього фінансового контролю i внутрішнього аудиту в тому числі є актуальними.

Основним завданням підрозділів аудиторської служби є надання керівникам об’єктивних і незалежних висновків та рекомендацій для забезпечення 
ефективного управління бюджетними коштами та ресурсами. На сьогоднішній день, сил підрозділів служби внутрішнього аудиту є недостатньо для проведення суцільної перевірки всіх військових частин, установ, організацій Міністерства оборони України. Таким чином, виникає нагальна необхідність у якісному плануванні заходів аудиторських перевірок з метою охоплення аудиторськими перевірками об’єктів, в яких ідентифіковано найбільші загрози та ризики.

\section{2. Аналіз останніх досліджень та публікацій}

Систематизація літературних джерел, аналіз підходів до вирішення проблеми ризик-орієнтованого планування, цілі зазначені у Стратегії на 20172020 (2017) роки, міжнародний приклад з проведення внутрішніх аудитів (Наказ Міністерства фінансів України від 04.10.2011 № 1247, 2011) та наявність власного практичного досвіду з організації планування аудиторської діяльності засвідчили про те, що питання планування на підставі оцінки ризиків у діяльності Міністерства оборони та Генерального штабу потребує подальшого дослідження та вдосконалення.

Питання, пов’язані із внутрішнім аудитом, його теоретичну площину вивчали такі науковці, як О. Брадул (2019), І. Дрозд (2012), Л. Книжник (2015), Т. Копотієнко (2017), М. Нежива (2017), I. Стефанюк (2011), I. Ткач (2019), А. Лойшин (2019) та інші.

Аналіз реформування системи державного внутрішнього фінансового контролю та практичні аспекти аудиторської діяльності досліджували вітчизняні фахівці такі як М. Бариніна (2018), І. Ткач (2018).

\section{3. Постановка завдання}

Методичним інструментарієм проведеного дослідження стали методи аналізу, синтезу, індукції та дедукції, періодом дослідження обрано роки функціонування саме аудиторської служби в системі Міністерства оборони України, а саме період з 2011 року (Постанова Кабінету Міністрів України від 28.09.2011 № 1001; Наказ Міністерства Фінансів України від 29.09.2011 № 1217; Наказ Міністерства оборони України від 14.11.2012 № 753) по теперішній час. Об’єктом дослідження є система внутрішнього аудиту в державному секторі та зокрема в Міністерстві оборони України.

Метою cmammi с проведення аналізу діючої нормативно-правової бази щодо впровадження ризик-орієнтованого планування в аудиторську діяльність. Доведення важливості даного напрямку в контексті отриманого економічного ефекту від правильно спланованих заходів. Обгрунтування комплексу теоретичних i практичних рекомендацій щодо удосконалення зазначеного процесу в Міністерстві оборони України.

Для забезпечення досягнення мети статmі пропонується:

по-перше, розкрити етапи ризик-орієнтовного планування і зупинитися на найбільш важливих і складних. На нашу думку, такими є перший і другий етапи;

по-друге, провести аналіз першого і другого етапів ризик-орієнтованого планування; 
по-третє, на основі зробленого аналізу, виявити наявні проблеми i обгрунтувати рекомендації з метою практичного застосування в Міністерстві оборони України розроблених методичних підходів із ризик-орієнтовного планування і приведення до міжнародних стандартів.

\section{2. Виклад основного матеріалу}

2.1. Як міжнародні, так i Національні стандарти внутрішнього аудиту вимагають розробки плану аудиторської діяльності на основі ризикорієнтованого відбору об’єктів аудиту. Це в свою чергу пов'язано із обмеженістю ресурсів підрозділу внутрішнього аудиту i з бажанням якомога ефективніше використати спроможності Служби та направити зусилля саме на дослідження найбільш ризикових об'єктів.

Відповідно до статті 26 Бюджетного кодексу України (2010) та Порядку здійснення внутрішнього аудиту та утворення підрозділів внутрішнього аудиту, затвердженого постановою Кабінету Міністрів України від 28.09.2011 № 1001 (2011) Департаментом внутрішнього аудиту Міністерства оборони України видано Тимчасову настанову з ризик-орієнтованого планування від 04.12.2017 № 42 (2017) (далі - Настанова).

Метою видання зазначеного документа $є$ регламентація ряду важливих питань в системі внутрішнього аудиту, а саме:

визначення комплексу дій 3 формування, погодження та затвердження ризик-орієнтованих планів підрозділів Служби внутрішнього аудиту Збройних Сил України (далі - Служба);

запровадження у Службі, що складається 3 Департаменту внутрішнього аудиту Міністерства оборони України (далі - Департамент) та територіальних управлінь внутрішнього аудиту (далі - територіальні управління), єдиних підходів до ризик-орієнтованого планування;

надання аудиторам методологічних та практичних рекомендацій з ризикорієнтованого планування.

Аналіз Настанови (2017) встановив, що відповідальність за якісне планування на рівні Служби покладається на керівників структурних підрозділів Департаменту, начальників територіальних управлінь за функціонально-галузевим та територіальним принципами. Загальна координація процесу планування та контроль покладається на відділ організації та забезпечення якості внутрішнього аудиту Департаменту (далі - Відділ організації).

Процес планування поділений на 5 етапів, а саме:

1 етап - складання всесвіту аудиту та визначення кількісних спроможностей Служби;

2 етап - ідентифікація подій та оцінка ризиків;

3 етап - консультації з керівництвом та відповідальними за діяльність;

4 етап - визначення пріоритетів, складання і затвердження планів;

5 етап - оприлюднення річних планів, направлення їх копій до Міністерства фінансів України та територіальних управлінь.

Слід зазначити, що п. 1.5 Настанови (2017) зроблено застереження, щодо частоти та періодичності проведення аудитів одного об'єкту (підконтрольного 
суб’єкту), що залежить від величини всесвіту аудиту, пріоритетів, результатів оцінки ризиків та спроможностей Служби.

Дослідженням охоплено перші два етапи, які, на думку авторів, є найбільш важливішими та потребують додаткового дослідження.

Відповідальні за планування використовують при плануванні бази даних документ, що складається і ведеться підрозділом Служби, затверджується іiі керівником і містить:

найменування підконтрольного суб'єкта, його код за Єдиним державним реєстром підприємств та організацій України та місцезнаходження;

найменування та код програмної класифікації видатків та кредитування всіх бюджетних програм (підпрограм);

адміністративні послуги, що надаються підконтрольним суб'єктом, контрольно-наглядові функції;

теми та дати виконання попередніх аудиторських завдань та період, за який вони проводилися;

відомості про стан реагування на висновки та рекомендації (пропозиції) за їх результатами.

База даних за потреби може додатково містити іншу інформацію 3 урахуванням особливостей діяльності Служби. Департаментом формується та ведеться зведена база даних, яка включає дані всіх підрозділів Служби. Особливості ведення баз даних і зведеної бази даних визначаються директором Департаменту відповідно до Стандартів внутрішнього аудиту (2011), наказів Міноборони, інших нормативно-правових актів.

Слід звернути увагу, що зазначеної інформації недостатньо для проведення роботи з ідентифікації та оцінки ризиків по кожному підконтрольному суб'єкту (об'єкту). Відповідно при плануванні також використаються наступні документи: накопичувальні страви, які формуються за функціонально-галузевим i територіальним принципами, карти гарантій та за потреби береться до уваги інша інформація статистичного або оперативного характеру.

В подальшому необхідно здійснити обгрунтований та достовірний аналіз, який потребує певних зусиль і значного обсягу часу.

2.2 Перший етап планування. При аналізі першого етапу планування необхідно зосередитись на складанні всесвіту аудиту та визначення кількісних спроможностей Служби.

Всесвіт аудиту, відповідно до визначення Настанови (2017), це сукупність об’єктів аудиту та підконтрольних суб'єктів, які можливо окремо дослідити під час аудиту.

Об’єкти аудиту - є діяльність суб'єктів в повному обсязі або окремі види діяльності, функції, загальні процеси (закупівлі, будівництво житла, ремонт військових об'єктів, облік військового майна, бухгалтерський облік і фінансова звітність, управління об'єктами державної власності, управління дебіторською та кредиторською заборгованостями, управління персоналом тощо), які включаються до всесвіту аудиту за принципом функціонального аналізу діяльності Міноборони та Збройних Сил (горизонтальний аналіз). 
Підконтрольні суб'єкти - департаменти та інші структурні підрозділи Міноборони та Генерального штабу, органи військового управління, військові частини, установи, організації, підприємства, об'єднання підприємств, окремі структурні підрозділи підприємств тощо, які включаються до всесвіту аудиту за принципом організаційної структури (вертикальний аналіз).

Всесвіт аудиту Департаменту охоплює:

об'єкти (суб'єкти) стратегічного рівня,

територіального управління - оперативного і оперативно-тактичного рівня;

служби аудиту - усі три рівні (початкова ступінь деталізації визначається директором Департаменту з подальшим уточненням під час проведення оцінки ризиків).

Крім того, при плануванні аудиторської діяльності доцільно будувати простір аудиту не тільки за вертикальним розподілом, а враховувати i горизонтальний розподіл, який базується на напрямах діяльності установи, специфічних процесах або функціях.

Також, під час 1 етапу планування здійснюється визначення кількісних спроможностей (кількості аудитів, що можуть бути проведені протягом планового періоду) та періоду аудиту (кількості років, протягом яких аудитами може бути охоплено весь всесвіт аудиту).

Загальний плановий фонд робочого часу на проведення аудитів розраховується для Департаменту та територіальних управлінь на підставі:

фактичної чисельності військовослужбовців, державних службовців та працівників Збройних Сил України, на яких покладено повноваження щодо проведення аудиту (далі - аудитори);

загального фонду робочого часу кожного аудитора (220 робочих днів на рік); коефіцієнтів для кожної категорії аудиторів.

2.3. Другий етап планування. На другому етапі планування здійснюється ідентифікація подій та оцінка ризиків.

Оцінка ризиків внутрішнього аудиту - етап планування діяльності 3 внутрішнього аудиту, на якому вивчаються об'єкти аудиту 3 найбільш високим рівнем ризику. Відповідно результати оцінки ризиків слугують базою для формування плану діяльності з внутрішнього аудиту. Стратегічний та річні плани формуються на підставі оцінки ризиків діяльності Міноборони, Генерального штабу у розрізі елементів всесвіту аудиту (об'єктів та підконтрольних суб'єктів), що визначає теми аудитів.

Аудиторській оцінці ризиків передує аналіз документальних джерел, які допоможуть виявити зміни у всесвіті аудиту та окремі ризики (наприклад, нормативно-правові акти, стратегічні плани, звітність, звіти попередніх аудитів та інших контрольних заходів, проведених внутрішніми та зовнішніми надавачами гарантій). Також, необхідно провести комплексну оцінку i актуалізацію всіх елементів всесвіту аудиту.

Ідентифікуються події кожного елемента всесвіту аудиту (зовнішні та внутрішні), які можуть вплинути на досягнення цілей та які, залежно від їх впливу, поділяються на можливості (позитивний вплив) і ризики (негативний вплив). Події, що створюють ризики, групуються та заносяться до переліку. 
Наведемо приклад такого переліку, а саме (табл. 1):

Таблицяя 1.

Варіант групування ризиків

\begin{tabular}{|c|c|c|c|c|c|}
\hline \multicolumn{6}{|c|}{ Ризики } \\
\hline $\begin{array}{c}\text { Впливу на } \\
\text { людей }\end{array}$ & IT та зв’язок & $\begin{array}{c}\text { Нормативно- } \\
\text { правові }\end{array}$ & Фінансові & $\begin{array}{c}\text { Операційні } \\
\text { (операційно- } \\
\text { технологічні) }\end{array}$ & Репутаційні \\
\hline \multicolumn{6}{|c|}{ Події, що створюють ризики } \\
\hline $\begin{array}{l}\text { Втрата } \\
\text { кваліфіковано } \\
\text { го персоналу } \\
\text { через } \\
\text { плинність } \\
\text { кадрів, вихід } \\
\text { на пенсію, } \\
\text { організаційно } \\
\text {-штатні } \\
\text { зміни, } \\
\text { скорочення }\end{array}$ & $\begin{array}{l}\text { втрата } \\
\text { Інтернет } \\
\text { зв’язку }\end{array}$ & $\begin{array}{l}\text { відсутність, } \\
\text { суперечність } \\
\text { або нечітка } \\
\text { регламентаці } \\
\text { я суттєвих } \\
\text { Положень } \\
\text { законодавств } \\
\text { a }\end{array}$ & $\begin{array}{l}\text { зменшення } \\
\text { фінансування, } \\
\text { або зменшення } \\
\text { надходжень } \\
\text { доходів }\end{array}$ & $\begin{array}{l}\text { втрата або } \\
\text { неможливість } \\
\text { доступу до } \\
\text { приміщень }\end{array}$ & $\begin{array}{l}\text { негативна } \\
\text { публічна } \\
\text { інформація }\end{array}$ \\
\hline $\begin{array}{l}\text { незадоволенн } \\
\text { я особового } \\
\text { складу }\end{array}$ & $\begin{array}{l}\text { втрата } \\
\text { телефонного } \\
\text { зв’язку }\end{array}$ & $\begin{array}{l}\text { розбіжності у } \\
\text { позиціях } \\
\text { зацікавлених } \\
\text { органів, які } \\
\text { мають } \\
\text { погодити } \\
\text { проект } \\
\text { нормативно- } \\
\text { правового } \\
\text { акта }\end{array}$ & $\begin{array}{l}\text { зменшення } \\
\text { надходжень від } \\
\text { трастових } \\
\text { фондів та (або) } \\
\text { благодійної } \\
\text { допомоги, } \\
\text { втрата грантів }\end{array}$ & $\begin{array}{l}\text { збої у роботі } \\
\text { комунальних } \\
\text { мереж }\end{array}$ & $\begin{array}{l}\text { незадоволенн } \\
\text { я } \\
\text { військовослу } \\
\text { жбовців та } \\
\text { членів їх } \\
\text { сімей } \\
\text { (звернення, } \\
\text { скарги) }\end{array}$ \\
\hline $\begin{array}{l}\text { довготерміно } \\
\text { ві вакансії }\end{array}$ & $\begin{array}{l}\text { виток } \\
\text { інформації }\end{array}$ & $\begin{array}{l}\text { порушення } \\
\text { контрактів } \\
\text { (угод) }\end{array}$ & $\begin{array}{l}\text { іммобілізація } \\
\text { коштів у } \\
\text { довгострокову } \\
\text { заборгованість }\end{array}$ & $\begin{array}{l}\text { відсутність } \\
\text { транспорту }\end{array}$ & $\begin{array}{l}\text { негативна } \\
\text { інформація } \\
\text { від } \\
\text { правоохорон } \\
\text { них органів } \\
\end{array}$ \\
\hline $\begin{array}{l}\text { висока } \\
\text { плинність } \\
\text { керівництва } \\
\text { та персоналу }\end{array}$ & $\begin{array}{l}\text { вірусні } \\
\text { атаки }\end{array}$ & $\begin{array}{l}\text { порушення } \\
\text { положень } \\
\text { законодавств } \\
\text { a }\end{array}$ & $\begin{array}{l}\text { відсутність } \\
\text { обігових коштів } \\
\text { для здійснення } \\
\text { платежів }\end{array}$ & $\begin{array}{l}\text { збої у роботі } \\
\text { важливих } \\
\text { механізмів, } \\
\text { апаратів }\end{array}$ & $\begin{array}{l}\text { негативне } \\
\text { обговорення } \\
\text { у політичних } \\
\text { колах }\end{array}$ \\
\hline $\begin{array}{l}\text { виробничі, } \\
\text { або військові } \\
\text { травми }\end{array}$ & $\begin{array}{l}\text { збої } \\
\text { апаратного } \\
\text { забезпеченн } \\
\text { я }\end{array}$ & $\begin{array}{l}\text { судові } \\
\text { позови, } \\
\text { зупинення } \\
\text { важливої } \\
\text { діяльності }\end{array}$ & $\begin{array}{l}\text { штрафи, пені, } \\
\text { неустойки }\end{array}$ & $\begin{array}{l}\text { невідповідність } \\
\text { обладнання чи } \\
\text { техніки }\end{array}$ & $\begin{array}{l}\text { негативні } \\
\text { повідомлення } \\
\text { про } \\
\text { керівництво }\end{array}$ \\
\hline $\begin{array}{l}\text { загибель } \\
\text { людей }\end{array}$ & $\begin{array}{l}\text { знищення } \\
\text { найбільш } \\
\text { важливих } \\
\text { даних або } \\
\text { неможливіс } \\
\text { ть доступу } \\
\text { до них }\end{array}$ & $\begin{array}{l}\text { низький } \\
\text { рівень } \\
\text { претензійно - } \\
\text { позовної } \\
\text { роботи }\end{array}$ & $\begin{array}{l}\text { втрата коштів } \\
\text { чи активів }\end{array}$ & $\begin{array}{l}\text { відсутність } \\
\text { матеріальних } \\
\text { запасів }\end{array}$ & $\begin{array}{l}\text { негативний } \\
\text { вплив на } \\
\text { репутацію } \\
\text { Міноборони } \\
\text { та Збройних } \\
\text { Сил }\end{array}$ \\
\hline
\end{tabular}

В подальшому повинна бути здійсненна актуалізація (уточнення) переліку ризиків. В даному випадку, кількість ризиків, яка може бути ідентифікована не уточняється та не обмежується, що ускладнює подальшу роботу з оцінки ризиків. В процесі ризик-орієнтованого планування пропонується ідентифікувати тільки 
найактуальніші, але не більше 7 ризиків, що безумовно є досить важливим в питанні планування внутрішнього аудиту.

Далі, пропонується здійснити оцінку кожного ризику з визначенням ймовірності настання подій та розмірів їх наслідків, які мають ймовірність здійснення негативного впливу на:

виконання Міністерством оборони, Генеральним штабом, підконтрольними суб'єктами завдань і досягнення цілей, визначених у стратегічних та річних планах;

ефективність планування, виконання та результати виконання бюджетних програм (підпрограм);

якість надання адміністративних послуг та здійснення контрольнонаглядових функцій, завдань, визначених актами законодавства;

стан збереження підконтрольними суб'єктами активів та інформації;

стан управління підконтрольними суб'єктами державним (військовим) майном, об'єктами держаної власності;

правильність ведення підконтрольними суб'єктами бухгалтерського обліку та достовірності фінансової і бюджетної звітності.

Наступним кроком пропонується зробити оцінку ідентифікованих (невід'ємних) ризиків на предмет ймовірності їх настання за критеріями:

дуже ймовірно або навіть напевно, подія вже відбувається або скоро очікується (з вірогідністю 67-100\%) - оцінка висока, дорівнює 3 балам;

ймовірно, що подія відбувається у майбутньому через 1-2 роки (3 вірогідністю 34-66\%) - оцінка середня, дорівнює 2 балам;

малоймовірно або у далекому майбутньому (з вірогідністю 0-33\%) - оцінка низька, дорівнює 1 балу.

Як приклад, розглянемо порядок оцінки одного із ризиків, а саме ризику: “Часті зміни керівництва, тимчасове керівництво та його зміни”. Даний ризик має вплив на всі шість запропонованих події. Відповідно може вплинути:

на досягнення цілей та виконання завдань;

на ефективність планування, виконання та результати виконання бюджетних програм (підпрограм);

на якість надання адміністративних послуг та здійснення контрольнонаглядових функцій;

на стан збереження підконтрольними суб'єктами активів та інформації;

на правильність ведення підконтрольним суб'єктом бухгалтерського обліку та достовірності фінансової і бюджетної звітності.

Тобто, подальший оцінці вже підлягає шість ризикових подій. Відповідно по кожній ризиковій події необхідно встановити:

чи були вони враховані системою внутрішнього контролю підконтрольного суб'єкта;

оцінити відповідність (правильність) обрання заходів по попередженню ризиків;

здійснити оцінку остаточного (невід’ємного) ризику.

Далі, кожна із шістьох ризикових подій оцінюється по ймовірності настання даних подій з обранням оціночного балу від 1 до 3. Обрання вірогідності у 
процентному відношенні та ймовірності запропоновано здійснювати колегіальним способом шляхом застосування суб'єктивних оцінок виконавців, що в свою чергу передбачає проведення дискусій, або так званого “мозкового штурму".

Наступним кроком - $є$ оцінка впливу визначених ризикових подій із застосуванням критеріїв:

фінансовий вплив;

вплив на людей;

вплив на боєздатність;

вплив на репутацію, етичні питання, підзвітність.

Тобто, визначених шість ризикових подій тепер потрібно оцінити за чотирма критеріями, загальна кількість застосованих оцінок ризику вже буде складати двадцять чотири, які зроблені за допомогою суб'єктивних суджень, шляхом проведення обговорень, консультацій та інших дій.

Слід зазначити, що кожна людина має своє сприйняття ризику та не рекомендується визначати ризики шляхом застосування середньоарифметичного значення рівня (балу) впливу ризику. Пропонується здійснювати оцінку впливу шляхом переговорів та дійти певного консенсусу.

Приклад запропонованого визначення рівня впливу наведено у таблиці (Таблиця 2).

Таблиия 2.

Оцінка рівня впливу ідентифікованих ризиків на діяльність об' скту

\begin{tabular}{|c|c|c|c|c|}
\hline \multirow{2}{*}{$\begin{array}{l}\text { Рівень } \\
\text { (оцінка - } \\
\text { бал) }\end{array}$} & \multicolumn{4}{|c|}{ Приклади визначення балів для критеріїв впливу: } \\
\hline & фінансовий вплив & вплив на людей & $\begin{array}{c}\text { вплив на } \\
\text { боєздатність }\end{array}$ & вплив на репутацію \\
\hline $\begin{array}{l}\text { Низький } \\
\text { (1) }\end{array}$ & $\begin{array}{l}\text { Фінансово- } \\
\text { матеріальний } \\
\text { вплив нижче } 100 \\
\text { тис. грн. }\end{array}$ & $\begin{array}{l}\text { Незапланована } \\
\text { відсутність } \\
\text { (хвороба, брак) } \\
\text { декількох } \\
\text { ключових осіб, } \\
\text { яка може } \\
\text { призвести до } \\
\text { деяких збоїв у } \\
\text { роботі }\end{array}$ & $\begin{array}{l}\text { Обмежене або } \\
\text { мінімальне } \\
\text { зниження } \\
\text { спроможностей, } \\
\text { швидке } \\
\text { відновлення }\end{array}$ & $\begin{array}{l}\text { Події (некомпетентність, } \\
\text { неналежне управління або } \\
\text { серйозне порушення правил } \\
\text { чи законодавства), які } \\
\text { приводять до зниження } \\
\text { довіри з боку невеликої } \\
\text { групи осіб (в окремому } \\
\text { колективі, громадськості на } \\
\text { місцевому рівні, групи } \\
\text { фахівців тощо). Період } \\
\text { відновлення довіри є } \\
\text { коротким }\end{array}$ \\
\hline $\begin{array}{l}\text { Середній } \\
\text { (2) }\end{array}$ & $\begin{array}{l}\text { Фінансово- } \\
\text { матеріальний } \\
\text { вплив вище } 100 \\
\text { тис. грн., але } \\
\text { нижче } 500 \text { тис. } \\
\text { грн. }\end{array}$ & $\begin{array}{l}\text { Незапланована } \\
\text { відсутність } \\
\text { (хвороба, брак) } \\
\text { декількох клю- } \\
\text { чових осіб, яка } \\
\text { може призвести } \\
\text { до суттєвих збоїв } \\
\text { у роботі }\end{array}$ & $\begin{array}{l}\text { Суттєве } \\
\text { зниження/втрата } \\
\text { спроможностей, } \\
\text { що заважає про- } \\
\text { довжувати вико- } \\
\text { нання завдань за } \\
\text { призначенням за } \\
\text { одним чи декіль- } \\
\text { кома напрямами } \\
\text { діяльності, шви- } \\
\text { дке відновлення }\end{array}$ & $\begin{array}{l}\text { Події (некомпетентність, } \\
\text { неналежне управління або } \\
\text { несистемне шахрайство чи } \\
\text { корупція у невеликих } \\
\text { масштабах, інші події), які } \\
\text { приводять до зниження } \\
\text { довіри з боку громадськості } \\
\text { на міжобласному чи } \\
\text { центральному рівні або з } \\
\text { боку важливих партнерів. } \\
\text { Період відновлення довіри є } \\
\text { коротким або помірним }\end{array}$ \\
\hline
\end{tabular}


ISSN 2522-9842@ Social development \& Security, Vol. 9, No. 4, - 2019

\begin{tabular}{|c|c|c|c|c|}
\hline \multirow{2}{*}{$\begin{array}{c}\text { Рівень } \\
\text { (оцінка - } \\
\text { бал) }\end{array}$} & \multicolumn{4}{|c|}{ Приклади визначення балів для критеріїв впливу: } \\
\hline & фінансовий вплив & вплив на людей & $\begin{array}{c}\text { вплив на } \\
\text { боєздатність }\end{array}$ & вплив на репутацію \\
\hline $\begin{array}{l}\text { Високий } \\
\text { (3) }\end{array}$ & $\begin{array}{l}\text { Фінансово- } \\
\text { матеріальний } \\
\text { вплив вище } 500 \\
\text { тис. грн., але } \\
\text { нижче } 1 \text { млн. грн. }\end{array}$ & $\begin{array}{l}\text { Серйозна травма } \\
\text { чи поранення, } \\
\text { загибель людини }\end{array}$ & $\begin{array}{l}\text { Значне } \\
\text { зниження/втрата } \\
\text { спроможностей, } \\
\text { що заважає про- } \\
\text { довжувати } \\
\text { виконання } \\
\text { завдань за } \\
\text { призначенням, } \\
\text { збої за } \\
\text { декількома } \\
\text { напрямами } \\
\text { діяльності, } \\
\text { повільне } \\
\text { відновлення }\end{array}$ & $\begin{array}{l}\text { Події (некомпетентність, } \\
\text { неналежне управління, } \\
\text { одноразове шахрайство чи } \\
\text { корупція у великих } \\
\text { масштабах, масштабне } \\
\text { одноразове, або системне } \\
\text { шахрайство чи корупція, } \\
\text { інші події), які приводять до } \\
\text { різкого зниження довіри } 3 \\
\text { боку громадськості на } \\
\text { міжнародному } \\
\text { регіональному рівні та з } \\
\text { боку важливих партнерів. } \\
\text { Період відновлення довіри } є \\
\text { помірним або тривалим }\end{array}$ \\
\hline $\begin{array}{l}\text { Дуже } \\
\text { Високий } \\
\text { (4) }\end{array}$ & $\begin{array}{l}\text { Фінансово- } \\
\text { матеріальний } \\
\text { вплив вище } \\
1 \text { млн. грн. }\end{array}$ & $\begin{array}{l}\text { Серйозні травми } \\
\text { чи поранення, } \\
\text { загибель людей }\end{array}$ & $\begin{array}{l}\text { Неспроможність } \\
\text { продовжувати } \\
\text { виконання } \\
\text { завдань за } \\
\text { призначенням, } \\
\text { суттєві втрати } \\
\text { спроможностей, } \\
\text { збої за всіма } \\
\text { напрямами } \\
\text { діяльності, } \\
\text { повільне } \\
\text { відновлення }\end{array}$ & $\begin{array}{l}\text { Події (некомпетентність, } \\
\text { неналежне управління, } \\
\text { великомасштабне } \\
\text { шахрайство чи корупція, } \\
\text { інші події), які приводять до } \\
\text { втрати довіри з боку } \\
\text { громадськості на } \\
\text { міжнародному } \\
\text { регіональному рівні та з } \\
\text { боку ключових партнерів. } \\
\text { Період відновлення довіри є } \\
\text { тривалим }\end{array}$ \\
\hline
\end{tabular}

Відповідно після визначення загальної оцінки ризику (загального балу) відповідно до побудованої матриці оцінки ризиків, формується реєстр ризиків.

Після оцінювання ризиків за ймовірністю настання і впливом, потрібно визначити у просторі пріоритетні об'єкти аудиту, здійснити відбір потенційних об'єктів аудиту, визначити частоту проведення планових внутрішній аудитів. Для цього у міжнародній практиці застосовують “фактори ризику”. В сучасному законодавстві даний термі може ще мати додатково назву "коригуючий коефіцієнт” або “фактор відбору”. До так званих додаткових “факторів ризику” або "факторів відбору” відносяться:

фінансова істотність (основним фактором ризику є обсяг фінансової діяльності, охопленої об'єктом аудиту);

складність діяльності (складні види діяльності важче виконати добре, тому підвищується ймовірність того, що вони будуть виконані неякісно або невчасно);

загальна політика внутрішнього контролю (при налагодженій політиці внутрішнього контролю ймовірність порушень і помилок значно зменшується);

репутаційна чутливість (деякі області діяльності можуть створювати значні ризики для репутації організації в цілому);

невід'ємний ризик (там, де є високий невід'ємний ризик, потрібні ефективні процеси контролю, що дозволяють знизити цей ризик. Внутрішній аудит повинен перевіряти ці механізми контролю регулярно); 
масштаби змін (висока плинність кадрів може знизити ефективність контролю, оскільки співробітники є менш досвідченими);

впевненість у керівництві (досвідчені керівники зазвичай вирішують проблеми більш ефективно і отримують кращі результати, ніж керівники без відповідного досвіду. Крім того, більш досвідчені керівники 3 більшою ймовірністю зможуть виявити ризики і прийняти відповідні рішення);

можливості для порушень (деякі системи і функції більш схильні до порушень і, навіть, до шахрайства та корупції);

дата останнього аудиту (час від часу аудити повинні проходити навіть на об’єктах з низьким рівнем ризику, а ті об'єкти, які не піддавалися аудиту вже протягом кількох років, можуть являти собою високий ступінь ризику).

Отже, для складання ризик-орієнтованого плану необхідно сформувати реєстр ризиків, скоригувати на загальний фактор відбору та на ваговий коефіцієнт.

Слід звернути увагу, що загальна кількість об’єктів та суб'єктів контролю складає приблизно 1500 одиниць, при застосуванні мінімальної кількості ризиків 7 одиниць на один підконтрольний суб'єкт (об’єкт), загальна кількість необхідних операцій може орієнтовано складати близька 252000 одиниць. До розрахунків не враховано час, який необхідно витратити для отримання (збирання) інформації для здійснення оцінки ризиків.

У дослідженні зроблено спробу обрахувати середню кількість затрачених людино/днів для проведення оцінки ризиків за всіма об'єктами та суб'єктами контролю.

Якщо врахувати застереження, щодо необхідності застосування колегіального обговорення та припущення, що більша частина особового складу відділу організації та збереження якості внутрішнього аудиту, у кількості 4 посадові особи, ніколи аудит самостійно не проводили. Тоді, при витраті 10 хвилин на оцінку одної операції, затрати трудових ресурсів складуть близько 2100 людино/днів, які необхідно врахувати з урахуванням виконання інших функціональних обов'язків.

Слід зазначити, що відповідно до вимог Стандартів з внутрішнього аудиту (2011) при плануванні проведення внутрішнього аудиту працівником підрозділу внутрішнього аудиту береться до уваги система управління ризиками, що застосовується в установі.

Відповідно до затверджених Постановою Кабінету Міністрів України від 12.12.2018 № 1062 “Основних засад здійснення внутрішнього контролю розпорядниками бюджетних коштів та внесення змін до постанови Кабінету Міністрів України від 28.09.2011 № 1001” (2018), здійснено розмежування внутрішнього контролю та внутрішнього аудиту, а одна з функцій внутрішнього аудиту полягає в оцінці ефективності функціонування системи внутрішнього контролю.

Також, Порядком організації в системі Міністерства оборони України внутрішнього контролю та управління ризиками, затвердженого наказом Міністра оборони України від 02.04.2019 №145 (2019) визначені формалізовані форми (План управління ризиками на відповідний рік та Структура бази даних 3 
управління ризиками), в яких зазначається інформація про розміри залишкових ризиків, після вжиття відповідних заходів самою установою.

Проте, необхідно визнавати, що більшість чинників ризиків визначено за допомогою суб'єктивних оцінок, припущень, які не засновано на абсолютних величинах. Суть ризик-орієнтованого підходу полягає в тому, що планування діяльності 3 внутрішнього аудиту повинно організовуватися в заздалегідь визначених певних площинах суттєвого ризику та на підставі залишкових ризиків. Тому, саме на оцінку залишкових (остаточних) ризиків і повинна бути спрямована діяльність внутрішнього аудиту під час здійснення ризикорієнтованого планування.

Також, слід зазначити, що запропоновані в даний час методичні підходи 3 оцінки ризиків при здійсненні планування діяльності з внутрішнього аудиту складені з урахуванням моделі внутрішнього контролю COSO (n./d.), а саме одного їі елементу - оцінки ризиків. Дана оцінка ризиків в установі проводиться з врахуванням вірогідності їх виникнення і впливу, з метою визначення того, які дії відносно них необхідно зробити.

На даний час, в практичній діяльності, підрозділами аудиторської Служби при здійсненні ризик-орієнтовного планування вже застосовуються розроблені набори загальних індикаторів ризику (“факторів ризику”). Як правило, дані набори індикаторів ризиків (факторів ризику) не сильно відрізняються за сутністю один від одного, проте вони надають можливість здійснювати оцінку кожного об'єкта та суб'єкта аудиту, визначати основні ризики їх діяльності та визначати їх пріоритетність. Проте, формалізованих форм щодо узагальнення досліджуваної інформації, за якими можливе якісне відображення результатів проведеної роботи $з$ оцінки ризиків, на даний час в підрозділах Служби не запроваджено.

Таким чином, керівниками підрозділів Служби внутрішнього аудиту повинна бути організована робота по збору інформації про стан внутрішнього контролю, процесів оцінки ризиків, стан фінансування, аналіз інформації в засобах масової інформації, що стосується діяльності в сфері Міністерства оборони України та Генерального Штабу Збройних Сил України. Перелічене дає змогу спрогнозувати майбутні ризики та встановити так звані “вузькі” місця в запровадженій системі внутрішнього контролю.

В подальшому фахівці Служби аудиту повинні проводити дослідження особливостей та специфіки діяльності структурних підрозділ Міністерства оборони та на підставі наявної інформації виокремлювати індикатори ризиків (фактори ризику).

Відповідно діяльність Служби спрямована на сприяння у досягнення Міністерством оборони визначених цілей шляхом здійснення ризикорієнтованих та об'єктивних аудитів, надання слушних пропозицій i рекомендацій, консультацій та обміну досвідом дає високі позитивні результати у вигляді економічного ефекту, наведено у таблиці (табл. 3). 
Табличя 3.

Економічний ефект від превентивних заходів

\begin{tabular}{|l|l|l|l|l|l|l|}
\hline \multicolumn{1}{|c|}{ Показники } & 2014 & 2015 & 2016 & 2017 & 2018 & $\begin{array}{c}2019 \\
\text { (січень- } \\
\text { червень })\end{array}$ \\
\hline $\begin{array}{l}\text { Опрацьовано пакетів документів } \\
\text { щодо ризикових операцій }\end{array}$ & 3446 & 6178 & 7982 & 10496 & 10955 & 2255 \\
\hline на суму, млрд грн & 17,4 & 68,2 & 70,9 & 64,9 & 78,5 & 30,6 \\
\hline Економічний ефект, млн грн & 57,6 & 895,9 & 488,8 & 909,0 & 412,2 & 239,7 \\
\hline $\begin{array}{l}\text { В тому числі в районі } \\
\text { проведення операцій } \\
\text { Об'єднаних сил, млн грн }\end{array}$ & - & 59,5 & 8,0 & 8,1 & 5,4 & 3,6 \\
\hline
\end{tabular}

Таким чином, стратегічною ціллю Служби є відповідність діяльності 3 внутрішнього аудиту національним стандартам 3 одночасною імплементацією міжнародних стандартів професійної практики на основі ризик-орієнтованого планування.

2.3. 3 огляду на результати проведеного дослідження, пропонується здійснювати оцінку ризиків при проведенні ризик-орієнтовного планування на основі використання індикаторів ризиків (факторів ризику), який покликаний вказати на проблемні ділянки та потенційні ризики у процесі складання та розробки ризик-орієнтованих планів (стратегічних та операційних).

Індикатори ризиків (фактори ризику) можна визначати підчас обговорень в підрозділах Служби внутрішнього аудиту (колегіальним органом). Слід зазначити, що в залежності від напрямів діяльності підконтрольних суб'єктів індикатори ризиків (фактори ризику) можуть бути різними (відмінними).

Дослідженням запропоновані індикатори ризиків (фактори ризику), які можуть бути використанні при проведенні оцінки ризиків для установи державного сектору та для державного підприємства.

Як приклад, для установи державного сектору пропонуються наступні індикатори ризиків (фактори ризику):

обсяг фінансування;

стан запровадженої системи внутрішнього контролю, результати проведеної роботи з оцінки ризиків та прийнятих заходів щодо їх попередження; термін, що пройшов з останнього контрольного заходу;

рівень впровадження пропозицій та аудиторських рекомендацій;

аудиторський висновок за результатами попереднього контрольного заходу; упевненість в керівництві підконтрольного суб'єкта;

публічна та з інших джерел інформація що стосується напряму діяльності підконтрольного суб'єкту, на підставі якої можливо спрогнозувати майбутні ризики та встановити так звані “вузькі” місця в запровадженій системі внутрішнього контролю.

Для державного підприємства:

зменшення обсягу чистого доходу в порівнянні з попереднім роком;

зменшення валового прибутку (тривалі збитки); 
щорічний показник фінансового результату;

зростаюча заборгованість (з кредиторами, 3 бюджетом, по виплатам заробітної плати);

стан запровадженої системи внутрішнього контролю, результати проведеної роботи з оцінки ризиків та прийнятих заходів щодо їх попередження; термін, що пройшов з останнього контрольного заходу;

рівень впровадження пропозицій та аудиторських рекомендацій;

аудиторський висновок за результатами попереднього контрольного заходу; упевненість в керівництві підконтрольного суб'єкта;

публічна та інша інформація 3 джерел, що стосуються напряму діяльності підконтрольного суб'єкту, на підставі якої можливо спрогнозувати майбутні ризики та встановити так звані "вузькі" місця в запровадженій системі внутрішнього контролю.

\section{3. Висновки і перспективи подальших досліджень}

Оцінка можливих ризиків за допомогою запропонованих (визначених) індикаторів ризику (факторів ризику) надає можливість оцінити та спрогнозувати наявність проблематичних напрямів діяльності підконтрольних суб’єктів, встановити можливі (наявні) ризики порушень, які перешкоджають установі здійснити заплановані завдання, отримати якісні результати та досягти бажані цілі.

Перспективи подальшого дослідження вбачаються у практичному застосуванні попередньо вивчених науково-обгрунтованих індикаторів ризику (факторів ризику). Зазначене безумовно дасть змогу підвищити якість ризикорієнтованого планування заходів внутрішнього аудиту в процесі функціонування системи внутрішнього аудиту, як в системі Міністерства оборони України так і в Збройних Силах України.

Результати зазначеного дослідження можуть бути використані на загальнодержавному рівні за результатами їх апробації в системі Міністерства оборони.

Author details (in Russian)

\section{Повышение эффективности государственного контроля за счет внедрения системы риск-ориентированного планирования}

Юлия Луцик * Владимир Мирненко **, Виталий Бегма ***, Сергей Мазка ****, Константин Ульянов *****, Надежда Юркив ******

* Национальный университет обороны Украины имени Ивана Черняховского,

пр. Воздухофлотский, 28, г. Киев, 03049, Украина,

e-mail: julia.lutsik@gmail.com,

к.э.н.,

доцент кафедры экономики и финансового обеспечения.

** Нацуиональный университет обороны Украины имени Ивана Черняховского, 
пр. Воздухофлотский, 28, г. Киев, 03049, Украина,

e-mail:mirnenkovi@gmail.com,

д.т.н., профессор, Заслуженный работник образования Украины,

заведуюший кафедрой логистики Воздушных Сил.

*** Национальный институт стратегических исследований,

ул. Пирогова, 7а, г. Киев, 01030, Украина,

e-mail: begma@niss.gou.ua,

д.э.н., дочент,

ведущий научный сотрудник.

**** Центральное территориальное управление внутреннего аудита Департамента внутреннего аудита Министерства обороны Украины,

ул. Стрелецкая, 23, г. Винница, Украина,

e-mail: akulacristal@gmail.com,

заместитель начальника управления.

$* * * * * \kappa . \ni . H .$,

e-mail: uluanov132@gmail.com,

Независимый сертифицированный аудитор.

****** Национальный институт стратегических исследований,

ул. Пирогова, 7а, г. Киев, 01030, Украина,

e-mail: yurkiv_n@ukr.net,

д.э.н., профессор,

главный научный сотрудник отдела экономической безопасности.

Аннотация: Одной из важных международных практик внутреннего аудита является применение риск-ориентированного планирования при выборе объектов и субъектов аудита. В процессе исследования проанализированы соответствие деятельности по внутреннему аудиту национальным стандартам с одновременной имплементации международных стандартов профессиональной практики на основе риск-ориентированного планирования. В статье обобщены научные дискуссии по вопросу приведения внутреннего аудита в соответствии с международными стандартами, оценки рисков в процессе осуществления рискориентированного планирования аудиторской деятельности и изучение практического эффекта от внедрения системы риск-ориентированного планирования.

Доказано, что на сегодня, сил подразделений службы внутреннего аудита недостаточно для проведения сплошной проверки всех воинских частей, учреждений, организаций Министерства обороны Украины. Сформулирована необходимость в качественном планировании мероприятий аудиторских проверок с целью охвата именно таких объектов, в которых идентифицировано самые большие угрозы и риски. Вопрос риск-ориентированного планирования внутреннего аудита раскрыто в следующей логической последовательности: определена общая регламентацию указанного процесса, проведен анализ составляющих рискориентированного планирования и предложена методика разработки плана на основании риск-ориентированного отбора объектов аудита. В частности, подробно рассмотрены вопросы по определению рисков, проведения оценки рисков по соответствующим критериям, определение рисков с помощью баллов. В ходе проведенного исследования эмпирически подтверждено и теоретически доказано, что риск-ориентированное планирование является неотъемлемой и важной составляющей аудиторской деятельности. Доказана важность данного направления в контексте полученного экономического эффекта от превентивных мер. На основе сделанного анализа, выявлено имеющиеся проблемы и обоснован комплекс теоретических и практических рекомендации с целью усовершенствования указанного процесса в Министерстве обороны Украины и практического применения разработанных методических подходов с риск-ориентированного планирования. Результаты проведенного 
исследования могут быть полезными в процессе планирования аудиторской деятельности на соответствующий период.

Ключевые слова: аудит, планирование аудита, идентификация событий, оценка рисков, риск-ориентированное планирование.

\section{Author details (in English)}

\section{Improving the effectiveness of public financial control through the introduction of risk-oriented planning}

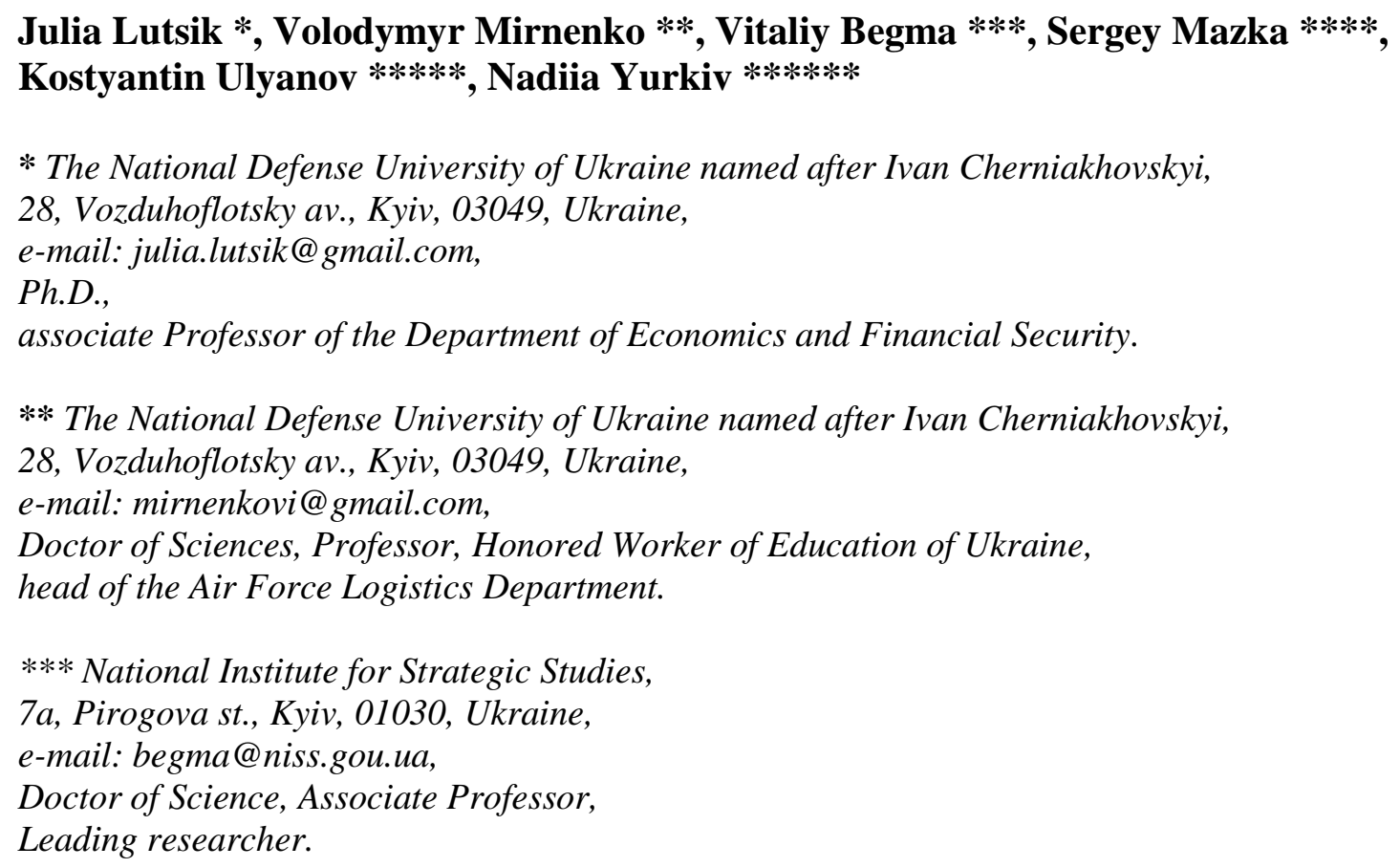

Abstract: One of the major international internal audit practices is the use of risk-based planning when selecting audit entities and entities. In the course of the study, the conformity of internal audit activities with national standards was analyzed, with the simultaneous implementation of international standards of professional practice based on risk-oriented planning. The article summarizes the scientific discussions on bringing internal audit in line with international standards, assessing risks in the process of risk-oriented planning of audit activities, and examining the practical effects of implementing a system of risk-oriented planning. 
It is proved that, as of today, the forces of the Internal Audit Service units are not enough to conduct a thorough inspection of all military units, institutions, organizations of the Ministry of Defense of Ukraine. The need for quality audit planning is formulated in order to cover precisely those entities that have identified the greatest threats and risks. The issue of risk-oriented planning of internal audit is revealed in the following logical sequence: the general regulation of this process is determined, the components of risk-oriented planning are analyzed and the method of plan development on the basis of risk-oriented audit selection is proposed. In particular, the issues of risk identification, risk assessment according to the relevant criteria, risk assessment using points are discussed in detail. The study empirically confirms and theoretically demonstrates that risk-oriented planning is an integral and important component of audit activity. The importance of this direction in the context of the obtained economic effect of preventive measures has been proved. On the basis of the analysis, the existing problems were identified and a set of theoretical and practical recommendations was substantiated with the purpose of improving the mentioned process in the Ministry of Defense of Ukraine and practical application of the developed methodological approaches to risk-oriented planning. The results of the study may be useful in planning the audit activity for the relevant period.

Keywords: audit, audit planning, event identification, risk assessment, risk-oriented planning.

\section{Використана література}

1. Брадул О.М. (2019). Аудит. Київ: Ліра-К, 2019.

2. Дрозд I. (2012). Внутрішній аудит у секторі державного управління. Казна України, 2, 6-8. URL: https://economic-vistnic.stu.cn.ua/index.pl?task=arcls\&id=969.

3. Книжник Л. (2015). Аудит в Україні: виклики та перспективи в умовах євроінтеграції. Collection of scientific works. Efficacy public administration, 44, URL: http://www.nbuv.gov.ua/node/2116.

4. Копотієнко Т.Ю., Нежива М.О. (2017). Теоретико-методичні аспекти реалізації концепції суттєвості в аудиті. Економіка $і$ суспільство, 10 (2017), 761-769. URL: http: //economyandsociety.in.ua/journal/10_ukr/129.pdf.

5. Міністерство фінансів України. Методологічні вказівки з внутрішнього аудиту в державному секторі. Київ: 2019.

6. Наказ Міністерства фінансів України від 04.10.2011 № 1247. (2011). Стандарти внутрішнього аудиту. URL: https://zakon.rada.gov.ua/laws/show/z1219-11.

7. Наказ Міністерства фінансів України від 29.09.2011 № 1217. (2011). Про затвердження Кодексу етики працівників підрозділу внутрішнього аудиту. URL: http://www.mil.gov.ua/diyalnist/vnutrishnij-audit/normativno-pravova-baza.html.

8. Наказ Міністерства оборони України від 14.11.2012 № 753. (2012). Про організацію діяльності з внутрішнього аудиту та затвердження Порядку проведення внутрішнього аудиту підрозділами Служби внутрішнього аудиту Збройних Сил України. URL: http://www.mil.gov.ua/diyalnist/vnutrishnij-audit/normativno-pravova-baza.html.

9. Наказ Департаменту внутрішнього аудиту Міністерства оборони України від 04.12.2017 № 42. Про Тимчасову настанову з ризик-орієнтованого планування.

10. Наказ Міністра оборони України від 02.04.2019 №145 (2019). Порядок організащії в системі Міністерства оборони України внутрішнього контролю та управління ризиками. URL: http://www.mil.gov.ua/diyalnist/vnutrishnij-kontrol.html.

11. Постанова Кабінету Міністрів України від 28.09.2011 № 1001. (2011). Деякі питання здійснення внутрішнього аудиту та утворення підрозділів внутрішнього аудиту. URL: http://zakon.rada.gov.ua/laws/show/1001-2011-п.

12. Постанова Кабінету Міністрів України від 12 грудня 2018 р. № 1062. (2018). Про затвердження Основних засад здійснення внутрішнього контролю розпорядниками бюджетних коштів та внесення змін до постанови Кабінету Міністрів України від 28 вересня 2011 р. № 1001. URL: https://zakon.rada.gov.ua/laws/show/1062-2018-п 
13. Рішення Ради національної безпеки і оборони України від 20 травня 2016 р. затверджене Указом президента України №240/2016 від 6 червня 2016 року № 240/2016. (2016). Про Стратегічний оборонний бюлетень Украӥни. URL: http://www.president.gov.ua/ documents/2402016-20137.

14. Розпорядження Кабінету Міністрів України від 08 лютого 2017 року № 142-р. (2017). Про схвалення Стратегії реформування системи управління державними фінансами на 2017-2020 роки. URL: https://zakon.rada.gov.ua/laws/show/142-2017-\%D1\%80.

15. Розпорядження Кабінету Міністрів України від 24 травня 2017 року № 415-р. (2017). Про затвердження плану заходів з реалізащії Стратегії реформування системи управління державними фінансами на 2017-2020 роки. URL: https://zakon.rada.gov.ua/laws/show/4152017-\%D1\%80.

16. Стефанюк I. (2011). Методологічні засади функціонування системи державного внутрішнього фінансового контролю в Україні. Фінанси України, 6(2011). URL: http://www.ac-rada.gov.ua/doccatalog/document/16738269/Stefanuk.pdf.

17. Barinina M. \& Ulianov K. (2018) Evolution of views on the appointment of financial and control bodies of the Ministry of Defense of Ukraine. Social development \& Security. 2(4), 59-68. DOI: http://doi.org/10.5281/zenodo.1237042.

18. Loishyn, Anatolii A., Tkach, Ivan M., Liashenko, Ihor O., Zinchenko, Andrii \& Lobanov, Anatolii A. Research of main international approaches for risk management process`s standardization in the context of internal control standardization in the Armed Forces of Ukraine and providing national security. Revista Espacios. Vol. 40 (No 20) URL: http://www.revistaespacios.com/a19v40n20/19402014.html

19. Loishyn, A., Tkach, I., Uhrynovych, O., Okipniak, D \& Potetiuieva, M. (2019). Risk management in defense program: Evidence from Ukrainian arm forces. Management Science Letters, 9(7), 1071-1082. DOI:10.5267/j.msl.2019.3.017.

20. COSO. (n./d.). The Committee of Sponsoring Organizations. URL: https://www.coso.org/ Pages/aboutus.aspx

21. Shpytal O. \& Tkach I. (2018). Justification of the validity of development internal control's indicators in the Ministry of Defense of Ukraine and the Armed Forces of Ukraine. Social development \& Security, 6(8), pp. 27-42. DOI: http://doi.org/10.5281/zenodo.2539655.

\section{References}

1. Bradul O.M. (2019). Audyt [Audit]. Kyiv: Lira-K, 2019.

2. Drozd I. (2012). Vnutrishniy audyt u sektori derzhavnoho upravlinnya [Internal audit in the public sector]. Kazna Ukrayiny, 2, 6-8. URL: https://economic-vistnic.stu.cn.ua/index.pl? task $=\operatorname{arcls} \& i d=969$.

3. Knyzhnyk L. (2015). Audyt v Ukrayini: vyklyky ta perspektyvy v umovakh yevrointehratsiyi [Audit in Ukraine: Challenges and Prospects in the Context of European Integration]. Collection of scientific works. Efficacy public administration, 44, URL: http://www.nbuv.gov.ua/node/2116.

4. Kopotiyenko T.YU., Nezhyva M.O. (2017). Teoretyko-metodychni aspekty realizatsiyi kontseptsiyi suttyevosti $\mathrm{v}$ audyti [Theoretical and methodological aspects of realization of concept of materiality in audit]. Ekonomika i suspil'stvo, 10 (2017), 761-769. URL:http: //economyandsociety.in.ua/journal/10_ukr/129.pdf.

5. Ministerstvo finansiv Ukrayiny. Metodolohichni vkazivky $z$ vnutrishn'oho audytu v derzhavnomu sektori [Methodological guidance on public sector internal audit]. Kyiv: 2019.

6. Nakaz Ministerstva finansiv Ukrayiny vid 04.10.2011 № 1247. (2011). Standarty vnutrishn'oho audytu [Internal Audit Standards]. URL: https://zakon.rada.gov.ua/laws/show/z1219-11.

7. Nakaz Ministerstva finansiv Ukrayiny vid 29.09.2011 № 1217. (2011). Pro zatverdzhennya Kodeksu etyky pratsivnykiv pidrozdilu vnutrishn'oho audytu [On approval of the Code of 
Ethics for Internal Audit Officers]. URL: http://www.mil.gov.ua/diyalnist/vnutrishnijaudit/normativno-pravova-baza.html.

8. Nakaz Ministerstva oborony Ukrayiny vid 14.11.2012 № 753. (2012). Pro orhanizatsiyu diyal'nosti z vnutrishn'oho audytu ta zatverdzhennya Poryadku provedennya vnutrishn'oho audytu pidrozdilamy Sluzhby vnutrishn'oho audytu Zbroynykh Syl Ukrayiny [On the organization of internal audit activities and approval of the Internal Audit Procedure by units of the Internal Audit Service of the Armed Forces of Ukraine]. URL: http://www.mil.gov.ua/ diyalnist/vnutrishnij-audit/normativno-pravova-baza.html.

9. Nakaz Departamentu vnutrishn'oho audytu Ministerstva oborony Ukrayiny vid 04.12.2017 № 42. Pro Tymchasovu nastanovu z ryzyk-oriyentovanoho planuvannya [About Temporary RiskOriented Planning].

10. Nakaz Ministra oborony Ukrayiny vid 02.04.2019 №145 (2019). Poryadok orhanizatsiyi v systemi Ministerstva oborony Ukrayiny vnutrishn'oho kontrolyu ta upravlinnya ryzykamy [The order of organization in the system of the Ministry of Defense of Ukraine internal control and risk management]. URL: http://www.mil.gov.ua/diyalnist/vnutrishnij-kontrol.html.

11. Postanova Kabinetu Ministriv Ukrayiny vid 28.09.2011 № 1001. (2011). Deyaki pytannya zdiysnennya vnutrishn'oho audytu ta utvorennya pidrozdiliv vnutrishn' oho audytu [Some issues of internal audit and the formation of internal audit units]. URL: http://zakon.rada.gov.ua/laws/show/1001-2011-p

12. Postanova Kabinetu Ministriv Ukrayiny vid 12 hrudnya 2018 r. № 1062. (2018). Pro zatverdzhennya Osnovnykh zasad zdiysnennya vnutrishn'oho kontrolyu rozporyadnykamy byudzhetnykh koshtiv ta vnesennya zmin do postanovy Kabinetu Ministriv Ukrayiny vid 28 veresnya 2011 r. № 1001 [On approval of the Fundamental Principles of Exercising Internal Control by Budget Managers and Amending the Cabinet of Ministers of Ukraine of September 28, 2011 No. 1001]. URL: https://zakon.rada.gov.ua/laws/show/1062-2018-p

13. Rishennya Rady natsional'noyi bezpeky i oborony Ukrayiny vid 20 travnya 2016 r. zatverdzhene Ukazom prezydenta Ukrayiny №240/2016 vid 6 chervnya 2016 roku № 240/2016. (2016). Pro Stratehichnyy oboronnyy byuleten' Ukrayiny [About the Strategic Defense Bulletin of Ukraine]. URL: http://www.president.gov.ua/documents/2402016-20137.

14. Rozporyadzhennya Kabinetu Ministriv Ukrayiny vid 08 lyutoho 2017 roku № 142-r. (2017). Pro skhvalennya Stratehiyi reformuvannya systemy upravlinnya derzhavnymy finansamy na 20172020 roky [On approval of the Strategy for reforming the system of public finance management for 2017-2020]. URL: https://zakon.rada.gov.ua/laws/show/142-2017-\%D1\%80.

15. Rozporyadzhennya Kabinetu Ministriv Ukrayiny vid 24 travnya 2017 roku № 415-r. (2017). Pro zatverdzhennya planu zakhodiv z realizatsiyi Stratehiyi reformuvannya systemy upravlinnya derzhavnymy finansamy na 2017-2020 roky [On approval of the plan of measures for the implementation of the Strategy of reforming the system of public finance management for 2017-2020.]. URL: https://zakon.rada.gov.ua/laws/show/415-2017-\%D1\%80.

16. Stefanyuk I. (2011). Metodolohichni zasady funktsionuvannya systemy derzhavnoho vnutrishn'oho finansovoho kontrolyu v Ukrayini [Methodological principles of functioning of the system of state internal financial control in Ukraine]. Finansy Ukrayiny, 6(2011). URL: http://www.ac-rada.gov.ua/doccatalog/document/16738269/Stefanuk.pdf.

17. Barinina M. \& Ulianov K. (2018) Evolution of views on the appointment of financial and control bodies of the Ministry of Defense of Ukraine. Social development \& Security. 2(4), 59-68. DOI: http://doi.org/10.5281/zenodo.1237042.

18. Loishyn, Anatolii A., Tkach, Ivan M., Liashenko, Ihor O., Zinchenko, Andrii \& Lobanov, Anatolii A. Research of main international approaches for risk management process`s standardization in the context of internal control standardization in the Armed Forces of Ukraine and providing national security. Revista Espacios. Vol. 40 ( $\mathrm{N}^{\mathrm{o}}$ 20) URL: http://www.revistaespacios.com/a19v40n20/19402014.html 
19. Loishyn, A., Tkach, I., Uhrynovych, O., Okipniak, D \& Potetiuieva, M. (2019). Risk management in defense program: Evidence from Ukrainian arm forces. Management Science Letters, 9(7), 1071-1082. DOI:10.5267/j.msl.2019.3.017.

20. COSO. (n./d.). The Committee of Sponsoring Organizations. URL: https://www.coso.org/ Pages/aboutus.aspx

21. Shpytal O. \& Tkach I. (2018). Justification of the validity of development internal control's indicators in the Ministry of Defense of Ukraine and the Armed Forces of Ukraine. Social development \& Security, 6(8), pp. 27-42. DOI: http://doi.org/10.5281/zenodo.2539655.

(C) 2019 by the authors; Social development \& Security, Ukrainian. This is an open access article distributed under the terms and conditions of the Creative Commons Attribution (CCBY) license (http://creativecommons.org/licenses/by/4.0/). 